2018 TheoLogica

An International Journal for Philosophy of Religion and Philosophical Theology

S.I. NEW THEMES IN ANALYTIC DOGMATIC THEOLOGY

DOI: https://doi.org/10.14428/thl.v0i0.1333

\title{
"THUS SAITH THE LORD": EDWARDSEAN ANTI-CRITERIALISM AND THE PHYSICALIST PROBLEM OF RESURRECTION IDENTITY
}

\author{
CHRISTOPHER WOZNICKI \\ Fuller Theological Seminary \\ christopherwoznicki@fuller.edu
}

\begin{abstract}
The doctrine of bodily resurrection is a core tenet of Christian faith, yet it is a doctrine fraught with several philosophical problems, the most significant of which concerns the persistence of personal identity. This is especially true for physicalist accounts of human nature. Here I put forth a possible solution to the problem of resurrection identity. Turning to the theology of the $18^{\text {th }}$ century American colonial theologian, Jonathan Edwards, as a resource, I argue for what I am calling "Edwardsean Anti-Criterialism." This is a form of anti-criterialism in which pre- and post-resurrection bodies are identical because God treats these bodies a metaphysically one. After providing a sketch of this view I defend Edwardsean Anti-Criterialism from two objections and provide three reasons why Christians might be inclined to accept this proposal.
\end{abstract}

Keywords: Anti-Criterialism, Identity, Jonathan Edwards, Metaphysics, Resurrection

The doctrine of bodily resurrection is a core tenet of the Christian faith. In fact, the inclusion of this doctrine in various creeds, confessions, and statements of faith makes one unable to call oneself an orthodox Christian while denying this doctrine. ${ }^{1}$ Moreover, the doctrine of resurrection is more than just dogmatically necessary, it is part and parcel of the gospel. Christians believe that an important part of the "good news" of the gospel is that death has been defeated in such a way that all believers will experience a resurrection like that of Christ. Despite the centrality of this doctrine to the Christian faith, it is fraught with several philosophical problems, perhaps the most significant

\footnotetext{
${ }^{1}$ See for example the Apostle's Creed which states "I believe...in the resurrection of the body and the life everlasting," the Nicene Creed which closes with "I look for the resurrection of the dead, and the life of the world to come," the Athanasian Creed which tells us that "All men shall rise again with their bodies. As examples of several confessions see the Westminster Confession of Faith which states that "all the dead shall be raised up, with the selfsame bodies" and Heidelberg Catechism which says that "Christ's resurrection is to us a sure pledge of our glorious resurrection."
} 


\section{CHRISTOPHER WOZNICKI}

problem arising from issues concerning the persistence of personal identity. This is especially true for physicalist anthropologies. In this essay I put forth a possible solution to this problem of identity, which I call "Edwardsean Anti-Criterialism." This is a form of anti-criterialism in which pre- and post- resurrection bodies are identical because God treats or constitutes these bodies as metaphysically one. No explanation, beyond divine fiat, can be said for why this is the case.

The plan of this essay is as follow: First, I clarify the physicalist problem of resurrection and personal identity over time. Second, I provide a brief summary of anticriterialism's contribution towards solving this problem. Third, I turn to the theology of the $18^{\text {th }}$ century American colonial theologian, Jonathan Edwards, in order to provide a sketch of what I am calling the Edwardsean Anti-Criterialist solution to the problem of resurrection identity. Having done this, in the final section I defend Edwardsean AntiCriterialism from various theological objections and provide several reasons for believing this account is theologically more attractive than others.

\section{Resurrection and Personal Identity over Time}

In the summer of 2016 my father died and was cremated. Naturally, his cremation brought up questions about resurrection and personal identity over time by his loved ones. ${ }^{2}$ How will he have the same body when he is resurrected? Does God gather up the ashes and then resurrect his body? What if the sub-atomic particles that made up his ashes become particles that make up some other object, even another person? These are certainly not new questions. For centuries Christians have wondered how they would receive their dead and decomposed bodies back on the day of the resurrection while at the same time saying "this is my body." 3 Theological reflection upon this problem has yielded numerous attempts at solving the problem of resurrection and personal identity. One well established manner of attempting to solve this problem has been to posit that humans are material bodies and immaterial souls. ${ }^{4}$ However, in recent years this view of human composition has fallen out of favor. Forms of physicalism are beginning to

\footnotetext{
${ }^{2}$ Of course they did not use the term "personal identity over time," though this captures what sort of questions they were asking.

${ }^{3}$ This seems to be a question that Paul is responding to in 1 Corinthians 15:35-58.

${ }^{4}$ One manner of approaching this problem has been to say that human beings are essentially material bodies and immaterial souls. However, this is not necessarily a solution to the problem. There are a number of important voices in the tradition who believe that (1) humans are material bodies and immaterial souls and (2) that each person's selfsame body will be what is raised. It is not a different and brand new body, but the same body. Examples of those who hold both of these premisses are Athenagoras, Augustine, and Aquinas. If one agrees with both of these premisses one would still need to give an account of how a person's resurrection body is properly the same body as their pre-resurrection body. Having the same soul is not enough, one also needs the same body. See (Davis 2002, 520-523).
} 
become the standard view. ${ }^{5}$ Given the prevalence of physicalist views of human composition I will limit myself to physicalist solutions to the problem of resurrection and personal identity over time.

The problem of resurrection and personal identity is especially difficult for physicalist accounts of human beings. Physicalists, i.e. those who propose that human beings are identical to or constituted solely by physical parts, must also be able to say that there is personal identity between pre-resurrection and post-resurrection human beings. This might be an especially difficult problem for physicalists. J.T. Turner provides a clear and concise explanation of why this is so. Turner notes that most metaphysicians affirm "Locke's Axiom," that is, "whatever begins to exist and then fails to exist, cannot begin to exist again." ${ }^{\prime}$ (Turner 2015: 89) According to some physicalist accounts, when a person dies, they simply fail to exist.7 This is problematic given Locke's Axiom, for this would yield the conclusion that the same human being cannot be brought back to life, i.e. "the resurrected body would be at best, a copy." (Turner 2015: 89) There are several ways for physicalists to avoid this untoward conclusion. One such way is to deny Locke's axiom, this however, would embracing a consequence that most metaphysicians are not willing to embrace. Another option is to provide some account of personal identity between pre-resurrection and post-resurrection human beings which avoids the "gappy existence" problem brought about by Locke's axiom. ${ }^{8}$ This latter option seems to be the modus operandi of most metaphysicians working on the problem of resurrection

\footnotetext{
${ }^{5}$ This is certainly true for the majority of contemporary philosophers and it is likely true of biologists, psychologists, and neurophysiologists as well. Although the many theologians would likely still identify with some form of dualism, as does the current author, there is a growing number of theologians that would identify with some form of physicalism.

${ }^{6}$ This content is from an unpublished revised version of James Turner's Dissertation, see (Turner 2015, 89). For more on why people are inclined to affirm Locke's Axiom, see (Gasser 2010, 1-17).

7 See for instance Joel Green's comments, "Death must be understood not only in biological terms, as merely the cessation of one's body, but as the conclusion of embodied life, the severance of all relationships, and the fading of personal narrative. It means that, at death, the person really dies; from the perspective of our humanity and sans divine intervention, there is no part of us, no aspect of our personhood, that survives death." (Green 2008, 179)

8 One model of resurrection which attempts to avoid the "gappy existence" problem is Dean Zimmerman's "Falling Elevator Model." See (Zimmerman 1999, 194-212) and (Zimmerman 2010, 33-50). This view seems to generate some significant theological problems, especially in the case of Jesus' resurrection. It also faces some significant philosophical objections. One such objection is that this view does not exclude cases of fission where there are two persons that are both alive and have the same immanent-causal connection to a previous person. In this case there would be no way to distinguish between two numerically identical persons. Another Model is Peter Van Inwagen's "Simulacra" view. In which "At the moment of each man's death, God removes his corpse and replaces it with a simulacrum, which is what is burned or rots." (Van Inwagen 1998, 49) One serious problem with this view, discussed by a number of objectors, is that it looks like it makes God out to be guilty of mass deception. This seems to be a rather negative consequence, one that most Christian physicalists would like to avoid.
} 
and personal identity. We shall now briefly turn to consider one way of working out this second option.

\section{Physicalist Solutions to The Problem of Resurrection and Personal Identity}

I intimated above that physicalists are especially concerned to avoid the problem of "gappy existence" that Locke's Axiom in conjunction with physicalism brings about for the doctrine of resurrection. In response to this problem numerous solutions have been proposed. ${ }^{9}$ One such solution that has not received serious consideration from a theological perspective is anti-criterialism. ${ }^{10}$ Anti-criterialisim is the view according to which there are no criteria for personal identity. Under this view criterion-based worries about the resurrection dissipate because criterialism itself has been rejected. (Merricks 2001: 195) I believe that a modified form of anti-criterialism is a promising potential solution to the problem of resurrection and personal identity over time, thus anticriterialism deserves a closer examination.

\subsection{Anti-Criterialism}

Anti-Criterialists claim to know that the dead will be resurrected and that personal identity will persist while conceding that there is "no hope for (and no need of) an explanation regarding how this miracle will occur." (Hudson 2007: 231) How can they make such a claim? They make it on the grounds that there simply are no criteria for personal identity. Eric Olson claims that this view is "poorly understood." (Olson: 2016) However this seems false, as we will see in what follows, Trenton Merricks, among others, has done much work to clarify the view that there are no criteria for personal identity. ${ }^{11}$

\footnotetext{
${ }^{9}$ For helpful surveys of several physicalist proposals for solving the problem of resurrection identity see: (Hudson 2007, 216-234). Some of these proposals include: (1) The replica view which was advocated by John Hick (Hick 1983, 126-127). (2) The "simulacra view" formerly argued for by Peter van Inwagen in "The Possibility of Resurrection," (van Inwagen 1978, 114-121). (3) The "falling elevator view" which can be found in Dean Zimmerman, (Zimmerman 1999, 194-212). (4) The constitution view as exemplified by Lynne Rudder Baker in The Metaphysics of Everyday Life (Baker 2007).

${ }_{10}$ The reader might wonder, "Isn't anti-criterialism a rather extreme metaphysical account? Why should we consider the most counterintuitive account before considering other accounts?" These are good questions. I take it that we should at the very least consider an anti-criterialist account of resurrection because: 1) Other accounts of resurrection identity attempt to provide a coherent account of resurrection in which the resurrected persons is numerically identical to persons or bodies before death. Yet all proposed identity-based accounts seem problematic in some significant way. 2) If anti-criterialism can help make sense of the Christian doctrine of resurrection, that may count as a reason for accepting it despite its counter-intuitiveness.

11 See various essays by Merricks including: (Merricks 2001, 183-200), (Merricks 1998a, 106-124), (Merricks 1998b, 261-286).
} 
Philosophical orthodoxy seem to demand that there are criteria of identity, that is, metaphysically necessary and sufficient conditions for identity over time. ${ }^{12}$ Merricks remarks than not just any sort of condition counts as a criterion. A criterion must also be informative. According to him a proposed criteria for personal identity is informative only "if one can, at least in principle, assert that they are satisfied without presupposing the identity for which they are said to be criteria." (Merricks 2001: 185) Merricks argues that there are no such criteria. His argument against criterialism amounts to showing that any possible criterion for personal identity over time results in a tautological proposition. Because such identity statements are tautological, they are not informative, and hence cannot truly be criteria.

Those looking to give an account of the resurrection might be disappointed by Merrick's position. There is something dissatisfying about not being able to say why pre-resurrection Jones is the same person as post-resurrection Jones. Thankfully, the anti-criterialist defender of the doctrine of bodily resurrection need not be disappointed for long. According to Merricks, accepting the denial of criterialism does not preclude there being some sort of explanation of identity holding across a temporal gap. Here I quote Merricks at length:

"The first step in this argument is to note that the claim that there are no criteria of identity does not imply that there are no informative sufficient conditions for identity. For example, it is consistent with the rejection of criterialism that an informative ${ }^{13}$ and metaphysically sufficient condition for $\mathrm{P}$ at $\mathrm{t}^{\prime}$ s being identical with $\mathrm{P}^{*}$ at $\mathrm{t}^{*}$ is that laws of nature $\mathrm{L}$ hold at $\mathrm{P}$ at $\mathrm{t}$ is related to $\mathrm{P}^{*}$ at $\mathrm{t}^{*}$ by biological process $\mathrm{B}$. So suppose, for the sake of argument, that that condition really is a sufficient condition for $\mathrm{P}$ at $\mathrm{t}^{\prime}$ s identity with $\mathrm{P}^{*}$ at $\mathrm{t}^{*}$. Then, if $\mathrm{P}$ at $\mathrm{t}$ satisfies this condition for being identical with $\mathrm{P}^{*}$ at $\mathrm{t}^{*}$, we thereby have an explanation of $\mathrm{P}$ at $\mathrm{t}^{\prime}$ s identity with $\mathrm{P}^{*}$ at $\mathrm{t}^{*}$." (Merricks 2001: 195-6)

Thus Merricks's anti-criterialism is consistent with there possibly being or actually being an explanation of personal identity between pre-mortem Jones and post-resurrection Jones.

Given the possibility of having an explanation for why a person's identity can persist despite a temporal gap, I want to put forth a plausible explanation (not criteria) for how this might be the case. To do so, I now turn to the theology of Jonathan Edwards.

\footnotetext{
${ }^{12}$ By "orthodoxy" I mean the received view which is overwhelmingly held to be true by

most philosophers. For example, I take it that most philosophers (and laypersons) believe that we could, in principle, provide the necessary and sufficient conditions for why I am the same person at 5 years old as when I am 65 years old.

${ }^{13}$ It should be noted that here Merricks is not using "informative" in the technical sense described above.
} 


\section{Jonathan Edwards on Personal Identity}

Jonathan Edwards was no stranger to issues concerning personal identity. ${ }^{14}$ In fact, the young Edwards thought deeply about John Locke's theory of identity, but, nevertheless opposed one version of it. ${ }^{15}$ Responding to Locke's view that personal identity only has a psychological criterion, Edwards says that,

"It is a mistake that it [personal identity] consists in sameness, or identity, of consciousness, if by sameness of consciousness, be meant, having the same ideas hereafter, that I have now, with a notion or apprehension that I had had them before; just in the same manner as I now have the same ideas, that I had in time past by memory." (Edwards 1980: 385)

Edwards poses a thought experiment in which I am annihilated. He says that it is conceivable that God could create two beings "each having all the ideas that are now in my mind, in the same manner that I should have by memory, if my own being were continued." (Edwards 1980: 386) Edwards tells us that our intuitions would lead us to deny that the two are "the same person with me." (Edwards 1980: 386) For Edwards this untoward result speaks against the veracity of Locke's theory. Thus Edwards went on to develop a unique theory of identity. To this theory we shall now turn.

\subsection{Edwards, Continuous Creation, and Identity}

Jonathan Edwards was keen on maintaining a doctrine in which God was the only a se being, that is, that God is the only being whose existence is in no way dependent, nor derived from, anything ad extra. ${ }^{16}$ Edwards was concerned with deistic impulses which were growing more and more popular by the day. These deists believed that divine power was mediated through the power given to created beings. (Helm 2003: 50) Thus created beings had the power, in and of themselves, to sustain their existence. ${ }^{17}$ Edwards's strong doctrine of aseity would not allow him to say this, and thus conclude

\footnotetext{
14 Paul Helm notes that Edwards's first biographer says, "Edwards read Locke while an undergraduate at Yale with 'more pleasure than the most greedy miser, when gathering up handfuls of silver ran gold from some newly discovered treasure." (Helm 2003, 45)

15 Though this particular writing against Locke wasn't published, it is from Edwards's notes as a college student. See (Merricks 2001, 189).

${ }^{16}$ Edwards's expresses his commitment to aseity when he says that, "God's making himself his end, in the manner that has been spoken of, argues no dependence, but is consistent with absolute independence and self-sufficience." (Edwards 1989, 462)

${ }^{17}$ In light of Jonathan Kvanvig and Hugh McCann's “The Occasionalist Proselytizer: A Modified Cathechism," it seems even more unlikely that this is the case. (Kvanvig and McCann 1991, 587-615)
} 
“THUS SAITH THE LORD"

that created beings were substances in a strong sense. Note his discussion in Original Sin,

"That God does, by his immediate power, uphold every created substance in being, will be manifest, if we consider, that their present existence is a dependent existence, and therefore is an effect, and must have some cause: and the cause must be one of these two: either the antecedent existence of the same substance or else the power of the Creator." (Edwards 1970: 400-1)

According to Edwards, deists believed that substances had maintained their existence because of their antecedent existence. In Edwards's mind this came too close to saying that some substances self-exist. God's aseity, his sole independent existence, would thereby be threatened. What Edwards needs to maintain his belief in God's sole aseity is a view that implies that insofar all substances exist, they exist by absolute dependence upon God. More specifically, any created substance exists only as long as, and only because God wills it. A view like this entails that creation at the first moment of its existence was constituted by nothing more than God's existence-conferring acts of willing it to be. This is interesting because it implies that "there is no difference between the first moment of a thing's existence and any subsequent moment of existence" in the sense that the first moment and subsequent moments are instances of creation from nothing. (Schultz 2016: 357) This is a doctrine of continuous creation.

It is now well established among Edwards scholars that Edwards believed God continuously creates the world ex nihilo at each moment. ${ }^{18}$ Note his now famous articulation of this doctrine:

"God's upholding created substance, or causing its existence in each successive moment, is altogether equivalent to an immediate production out of nothing, at each moment, because its existence at this moment is not merely in part from God, but wholly from him; and not in any part or degree, from its antecedent existence." (Edwards 1970: 402)

This view implies that the created world does not persist through time. If the created world does not persist through time, it is also the case that individual identities of persons do not persist through time. This means that Jones at $t^{1}$ is not identical with Jones at $t^{2}$ because they are materially different creations. This, however, seems counterintuitive to most person's experiences..$^{19}$ To most people it would seem that Jones at $t^{1}$ is

\footnotetext{
${ }^{18}$ For a slight deviation from this view see (Lee 2000, 63). There Lee argues that Edwards does not hold to continual creation ex nihilo in a simple sense. The "divinely established general laws are given permanence, and are in a sense not created ex nihilo at every moment."

19 Even though this might be counter to most people's experiences, Edwards believed that it is in principle, although maybe not in reality, it is possible for humans to experience continual creation. Thus, Edwards says, "The universe is created out of nothing every moment; and if it were not for our
} 


\section{CHRISTOPHER WOZNICKI}

identical in some sense with Jones at $\mathrm{t}^{2}$. How does Edwards get around this apparent discrepancy? He says that identity persists through time because God arranges that Jones is the aggregate of his various temporal and spatial parts. In Original Sin Edwards says,

"Some things, existing in different times and places, are treated by their Creator as one in one respect, and others in another; some are united for this communication, and others for that; but all according to the sovereign pleasure of the Fountain of all being and operation." (Edwards 1970: 405)

In other words, God regards Jones at $\mathrm{t}^{1}$ and Jones at $\mathrm{t}^{2}$ as one being, even though formally they are not. This seems to commit Edwards to the view that an individual at any given time is not strictly identical with anything at any other time, rather because of God's declaration, i.e. divine fiat, the person is actually a sum of four-dimensional parts, i.e. temporal parts. Edwards seems to be a perdurantist, although a person perdures solely by virtue of God's will.

We might want to ask several questions about this account. First, what is the view described above doing theologically for Edwards? As noted above, it gives Edwards a very strong account of aseity. God is the only being that is truly independent, created substances literally fall out of existence moment by moment, and come into existence $e x$ nihilo at every successive moment, thus everything at every moment is dependent upon God for its existence. Second, Edwards's perdurantist account allows him to say that God regards all humanity (barring Christ) as one with Adam thus making them, ontologically, one with Adam. ${ }^{20}$ Again, quoting Edwards's Original Sin,

"I am persuaded, no solid reason can be given why God who constitutes all other created union or oneness, according to his pleasure... may not establish a constitution whereby the natural posterity of Adam, proceeding form him, much as the buds and branches form the stock or root of a tree, should be treated as one with him, for the derivation, either of righteousness and communion in rewards, or of the loss of righteousness and consequent corruption of guilt." (Edwards 1970: 405)

In addition to asking, what is the view described above doing theologically for Edwards, we might ask, "Is Edwards's view truly perdurantism?" Perdurantism, is the view that an individual is an aggregate of discrete temporal parts. Endurantism, on the

imaginations, which hinder us, we might see that wonderful work performed continually, which was seen by the morning stars when they sang together." (Edwards 1980, 241-242)

${ }^{20}$ S. Mark Hamilton has argued that perhaps Edwards did not hold to an Augustinian realist account of Adam and the rest of humanity. He cites the similarities between William Ames and Edwards in order to make this argument. (Hamilton 2013, 413). 
other hand, is the view that a thing persists through time if and only if it exists wholly at different times. At first glance, Edwards's view seems to be a form of perdurantism. (Noonan and Curtis: 2017) We have said above, that Jones at $t^{1}$ and Jones at $t^{2}$ are not strictly identical, but that they are related by God's will, thus making Jones the sum of his four-dimensional parts. But is it really the case that Jones at $t^{1}$ and Jones at $t^{2}$ are temporal parts of Jones? It seems to me that it is not. Oliver Crisp notes that "if all objects are created moment by moment in the mind of God, then their perdurance is indeed an illusion which is perpetuated by the ordering by God of all things in a way that reflects his perfection and beauty." (Crisp 2005: 109) Perdurance might be a beautiful illusion, but an illusion nevertheless. We might get clearer on the claim that perdurance is an illusion. Consider Jones again. Perduranists would claim that Jones persists because Jones has the temporal and spatial parts Jones at $\mathrm{t}^{1}$, Jones at $\mathrm{t}^{2}$, Jones at $t^{3}$, etc. However, given Edwards's continuous creation Jones at $t^{1}$ no longer exists, because nothing can persist for more than a moment in time. Jones at $t^{2}$, does not exist either. Furthermore, no temporal part of Jones currently exists. All that exists is Jones ${ }^{\text {now. }}$ So Jones does not perdure, rather it seems that Jones endures, i.e. Jones ${ }^{\text {now }}$ exists wholly and completely at $\mathrm{t}^{\text {now, }}$, and at no other time. Does this completely undercut Edwards's account of the persistence of identity over time? Probably not. Edwards might still want to believe in the perfect and beautiful "illusion" of perdurance. (Crisp 2005: 109) Although perdurance isn't real, Edwards can still say that God regards Jones at $t^{1}$, Jones at $t^{2}$, Jones at $t^{3}$, etc. as Jones by divine fiat. This is not perdurance strictly speaking, nevertheless it is an account of how discrete objects which endure over time can be thought of as identical. ${ }^{21}$

We can now summarize what has been said above. Given Edwards's doctrine of continuous creation, what makes it such that any given object at $\mathrm{t}^{1}$ is the same object at $\mathrm{t}^{2}$ ? The answer is divine fiat. God regards object at $\mathrm{t}^{1}$ as the same object at $\mathrm{t}^{2}$, thus they simply are the same object. Yes, Edwards believes that identity is by divine fiat, but is that all there is to identity? Does God arbitrarily decide whom or what he will regard as one? No, he doesn't. Edwards believes there is a certain fittingness as to what God would regard as one by divine fiat. Paul Helm says that for Edwards, God "makes truth not whimsically or in a random fashion, but in accordance with his own wise purposes." (Helm 2003: 56) Crisp says that "this notion of being 'made one' that Edwards uses is not mere conventionalism." (Crisp 2005: 101) Crisp further elaborates saying that God does not simply gerrymander any old hunk of matter, e.g. a biscuit-fossil-locomotive. (Crisp 2005: 101) As Edwards says, constitution depends on nothing but divine will, but,

${ }^{21}$ If one remains unconvinced by the argument that Edward's theory of persistence is actually a form of endurantism, and chooses to believe that Edwards's theory of persistence is perdurantist one might want to hold to another version of perdurantism often called "stage theory." A case for Edwards as a stage-theorist see, (Rea 2007, 335-41). Oliver Crisp currently believes that Edwards holds to a stagetheoretic account of identity. See (Crisp 2016, 142-144). 


\section{CHRISTOPHER WOZNICKI}

"divine will depends on nothing but the divine wisdom." (Edwards 1970: 403) Thus, even though persistence of identity is in one sense arbitrary, it is fitting with divine wisdom.

\subsection{Edwards's Anti-Criterialism}

Although Edwards's appeal to divine wisdom allows him to give a reason why the divine fiat is fitting, the ultimate explanation for why an object at $\mathrm{t}^{1}$ is the same object at $\mathrm{t}^{2}$ is the divine prerogative. "Thus saith the Lord," so thus is the case. This seems to me to be a form of anti-criterialism. Remember, anti-criterialism (as put forward by Merricks) is the view that there are no criteria for identity. Merricks says that not just any sort of condition counts as a criterion. A criterion must also be informative. Something is informative only "if one can, at least in principle, assert that they are satisfied without presupposing the identity for which they are said to be criteria." (Merricks 2001: 185) It seems to me that Edwards's divine fiat account of the persistence of identity is not informative in this technical sense. However, someone might object, saying that the divine fiat account it actually is informative. Edwards has in fact given us an explanation of identity. The anti-criterialist need not deny that Edwards gives us an explanation. Remember Merricks claims the fact that there are no criteria of identity does not imply that there are no metaphysically sufficient explanations of identity and he provides an example of how this might be so. He says that, "It is consistent with the rejection of criterialism that an informative and metaphysically sufficient condition for $P$ at $t^{\prime}$ s being identical with $\mathrm{P}^{*}$ at $\mathrm{t}^{*}$ is that laws of nature $\mathrm{L}$ hold at $\mathrm{P}$ at $\mathrm{t}$ is related to $\mathrm{P}^{*}$ at $t^{*}$ by biological process B." (Merricks 2001: 195-6) Now suppose we replace "laws of nature L" and "biological process B" with something else, with something more Edwardsean. Then we end up with something like:

Edwardsean Anti-Criterialism (EAC): The metaphysically sufficient condition that Jones at $t^{\prime}$ s being identical with Jones* at $t^{*}$ is that the divine declaration holds that at Jones at $\mathrm{t}$ is related to Jones* at $\mathrm{t}^{*}$ by divine fiat. ${ }^{22}$

This seems entirely consistent with the anti-criterialist belief that there are no informative (in the technical sense) criteria for identity. The view described above, EAC, seems to be consistent with Edwards's anti-criterialist account of the persistence of identity over time.

Should we follow EAC in trying to solve the problem of resurrection identity? We might have reasons to do so, however there are some problematic consequences of

\footnotetext{
${ }^{22}$ Here the term "Edwardsean" is not meant to suggest that Edwards explicitly endorsed this view, only that it is consistent with his reasoning.
} 
Edwards's account of identity. Edwards's doctrine of continuous creation makes it so that, even though God regards Jones ${ }^{1}$ at $t^{1}$ and Jones ${ }^{2}$ at $t^{2}$ metaphysically one the reality is that there is no Jones simpliciter. At each moment of time a new Jones comes into existence and is obliterated before the next moment, when a new Jones is created. Jones does not persist long enough to act, thus we might believe Jones does not persist long enough to exercise any moral agency. Philip Quinn makes this point even more sharply. Speaking of the sin of Adam, Quinn comments:

"God has arbitrarily decided to treat a number of diverse instantaneous persons as one by endowing them with similar properties and relations and to create the illusion that some one person ate the forbidden fruit. But in sober truth no one of these instantaneous persons ate the forbidden fruit, for no one of them existed long enough to do so. Each one of them existed only long enough to perform an instantaneous part of that momentary action." (Quinn 1983: 66)

This, Quinn says, undercuts the doctrine of original sin. More drastically than that, theologically speaking, it undercuts moral responsibility for action in general! This is an extremely problematic entailment of Edwards's metaphysics. So should we abandon, EAC? Oliver Crisp does not think we should, and neither do I, because we can hold to EAC with a modified version of Edwards's metaphysics, what Crisp calls "Chastened Edwardsian Metaphysics." (Crisp 2005: 133)

Crisp, at the time, suggested that we might want to reconstruct Edwards's thinking along more mainstream perdurantist lines. Throwing off the encumbrance that is continuous creation, and thus the problems it creates, we could opt for the following, which is in more in line with mainstream perdurantism:

(P1) God treats the temporal parts of Jones as one (by divine fiat), privileging these parts on the basis that they share certain properties which are fitting with one another.

Or, if this is not strong enough, we might say that

(P2) God makes the temporal parts of Jones one (by divine fiat), privileging these parts on the basis that they share certain properties which are fitting with one another. ${ }^{23}$

${ }^{23}$ If one is worried that proposition (1) and (2) come too close to being criteria for identity, one can simply remove "privileging these parts on the basis that they share certain properties which are fitting with one another," thus emphasizing that the "oneness" comes wholly by divine fiat. I, however, am not worried that 1 and 2 come close to being criteria for identity because for Edwards "fittingness" is based purely on "divine wisdom." See section 3.1 above. 


\section{CHRISTOPHER WOZNICKI}

It seems to me that both (1) and (2) are compatible with EAC. Thus an Edwardsean AntiCriterialism does not require one to be on board with Edwards's entire metaphysics of identity and persistence through time. Edwards's anti-criterialism includes the belief in continuous creation, but Edwardsean Anti-Criterialism does not. Edwards's anticriterialism is actually a form of endurantism, whereas Edwardsean Anti-Criterialism is a form of perdurantism. Edwardsean Anti-Criterialism isn't the same as Edwards's anticriterialism. So what does EAC look like when applied to the problem of resurrection identity?

\subsection{Edwardsean Anti-Criterialism and Resurrection Identity}

Let us say that upon Jones's death, Jones's body is cremated. Jones's family decides to spread Jones's ashes throughout various parts of Yosemite (surely an illegal act, nevertheless, it was Jones's dying wish.) A theologically inquisitive funeral attendee thinks to herself, "Jones's 'body' is now a pile of ashes, to make things worse, it is spread all over Yosemite! What if some deer drinks his ashes from the river? What if the ashes blow away and end up in some hiker's sandwich! Oh gosh, what if his ashes decompose and become part of the fertilizer for one of the giant sequoias!" The theologically inquisitive funeral attendee, because of her familiarity with the creeds and confessions of her theological tradition, knows that in new creation God will give Jones back his body. But this seems problematic to her, because parts of Jones's body have now become part of other creature's bodies, even other human bodies. So how can God give Jones back his body in the eschaton? An Edwardsean Anti-Criterialist pastor, conducting the funeral, might say to the theologically inquisitive funeral attendee that God treats (P1) or constitutes (P2) Jones's pre-resurrection and his resurrection body as one. In new creation, God will say to Jones, "Thus saith the Lord, this is your body," and it will be true. Pre-resurrection Jones, which is now scattered throughout Yosemite, is a temporal part that God either treats or constitutes as one with Jones's resurrection body, some hunk of matter that God arranges. The theologically inquisitive funeral attendee might object, that this is an explanation of how Jones's pre-resurrection body and his resurrection body are one, but its not very informative in the technical sense, because it is tautological. To this, the pastor might say to her "you are absolutely correct, it is not informative, after all this is an anti-criterialist account of how identity persists through the resurrection. You might not be satisfied, but it is an explanation, and that is all we can possibly give." Pastorally insensitive, to be sure, but the response given accurately captures what I am calling the Edwardsean Anti-Criterialist solution to the problem of resurrection identity.

The following is a summary of how EAC may be a solution to the problem of resurrection identity: Christian orthodoxy demands that personal identity hold between 
my pre-resurrection and post-resurrection self. Assuming some form of physicalism, EAC states that personal identity holds because God treats or constitutes my preresurrection body and my post-resurrection body as metaphysically one. No reasons, beyond divine fiat, can be given for why this is the case. Thus, the demand of Christian orthodoxy that personal identity hold between my pre-resurrection and postresurrection self is fulfilled.

\section{The Strengths and Weaknesses of Edwardsean Anti-Criterialism}

Edwardsean Anti-Criterialism is $a$ solution to the problem of resurrection identity, but is it a good solution? What would constitute a good solution? Minimally, Christians might think that coherence with Scripture and Christian tradition or with other essential doctrines might lead one to believe a given proposal might be a good solution to this problem. I believe that EAC meets these criteria and more. Below I suggest what might be some of the strengths and weaknesses of this account.

\subsection{Strengths of Edwardsean Anti-Criterialism}

Even though it should be acknowledged that Edwards was an idealist, one important strength of this proposal is that EAC does not commit one to a particular theory about the composition of human persons. That is, even though we have been assuming some form of physicalism for the sake of argument, one could hold to holistic dualism, emergent dualism, a constitution view, idealism or any number of orthodox accounts of what constitutes human persons and still be an Edwardsean Anti-Criterialist. As it was noted in section one above, many accounts of what constitutes human persons suffer from the problem of the identity of resurrection bodies; the view proposed in this essay provides a solution for numerous theological anthropologies while not committing to any particular metaphysics of human persons.

In addition to the fact that EAC might fit with most theological anthropologies, this view fits nicely with minimalist dogmatic eschatological commitments. Dogmatically and confessionally most formulations of the resurrection will include a feature that claims that God is the sole guarantor of resurrection identity. ${ }^{24}$ Speaking of 1 Corinthians 15, but also the doctrine of the resurrection in general, Anthony Thiselton says that, "It is crucial to Paul's argument not only in 1 Corinthians 15 but also in Rom. 4:16-25, 2 Cor 1:9 and 5:1-10, and 1 Thess. 4:14-17 that resurrection from the dead constitutes a sheer gift of God's sovereign, creative grace, and not the fruition of latent capacities of the soul." (Thiselton 2012: 111) Thiselton claims that there is a common

${ }_{24}$ Ted Peters claims this is a requirement of any doctrine of resurrection, saying, "Theologically speaking, guaranteeing identity is God's task, not ours." (Peters 1999, 316) 


\section{CHRISTOPHER WOZNICKI}

view among Christians, which owes more to Plato and other religions than to Holy Scripture, that immortality derives from human capacities. Thus, any view which makes it seem as though contrast, continuity, and transformation through death into resurrection are human capacities comes awfully close to a non-scriptural account of the afterlife. Some of the physicalist accounts of how the problem of resurrection identity are solved come to close to placing the power for maintaining identity through death to creaturely powers rather than divine power. Consider for instance the Falling Elevator Model. In one version of this account, one could say that dead bodies just naturally fission into two, much like some bacteria undergo binary fission. The fission of bacteria is an entirely "natural" process, not involving special divine action. Might fission of a dead person be a "natural" part of the death process, like fission in bacteria? Perhaps. There are no reasons to necessarily say "no." Sure one could give a different account of how the fission occurs. Perhaps immediately prior to death, God intervenes and miraculously causes the body to fission such that the new body "jumps" into the afterlife while the old one stays behind. But nothing in the Falling Elevator Model necessitates God's special action in the act of fission. ${ }^{25}$ I take the lack of a necessary divine sovereign and creative act to be a weakness of this model. EAC on the other hand does not suffer from this weakness. There is no way to have EAC without saying that the persistence of personal identity through resurrection constitutes a sheer gift of God's sovereign, creative grace, and not the fruition of latent capacities of human beings. God is the sole guarantor of resurrection identity. Why is this the case? Because the identity between a pre-resurrection Jones and post-resurrection Jones comes by virtue of divine declaration. There is nothing about Jones herself that makes it so that Jones at $\mathrm{t}^{1}$ is Jones at $\mathrm{t}^{2}$; it is God's sovereign word that makes it the case that Jones at $\mathrm{t}^{1}$ is Jones at $\mathrm{t}^{2} .{ }^{26}$

${ }^{25}$ One anonymous reviewer made the following observation: "Why might God not create in such a way that the power for resurrecting is placed in the constitution of man itself? This wouldn't imply that resurrection is an utterly natural phenomenon; it would just mean that God in his providence and wisdom has endowed human beings with the (supernatural) capacity to resurrect if this conforms to God's will." This is a good point. If God were to supernaturally give human beings the capacity to resurrect if certain conditions are met, this would assuage the worry that resurrection might be naturalized. I take it, however, that the resurrection of dead is a special act of providence. The scenario suggested by the reviewer, would still be an act of providence, however it seems to me that it would be an act of God's providence in conserving the natural order of creation.

${ }_{26}$ One anonymous reviewer brought up the point that, "If the identity between a pre-resurrection Jones and post-resurrection Jones comes by virtue of divine declaration alone, then EAC seems to be undermined because no reference to properties which are fitting with one another seem to be required. The reference to such properties seems to amount to the view that there is something about Jones herself that makes it so that Jones at $\mathrm{t}^{1}$ is identical Jones at $\mathrm{t}^{2}$." Again, this is a good point. However, to say that "There is nothing about Jones herself that makes it so that Jones at $\mathrm{t}^{1}$ is Jones at $\mathrm{t}^{2}$ " is consistent with what we have said about fittingness above. This is because fittingness for Edwards is simply a matter of the divine will and wisdom. 
Above we noted that Edwards was concerned with deists believing that substances maintain their existence because of their antecedent existence, that is, an inherent power of self-existence within creatures. In Edwards's mind this came too close to saying that some substances self-exist. Thus, he developed a theology which stated that continued existence came solely through divine declaration. Much like Edwards was concerned about creatures having self-existence, here we are noting that one ought to be concerned with a resurrection account that posits the possibility of creatures to maintain identity through death by virtue of an inherent capacity. ${ }^{27}$ EAC blatantly denies this possibility. Under EAC identity is solely in virtue of a sovereign divine declaration, it is itself a divine creative (re-creative) act. ${ }^{28}$

Another strength, although not directly related to eschatology, is that this account helps to make sense of other doctrines, for instance the doctrine of original sin. EAC, as we have formulated it, comes out of Edwards's own doctrine of Original Sin. Although it is a modified version of Edwards's own account, it still holds explanatory power for how Adam's progeny have original sin and (potentially) how they might be guilty for Adam's sin. Although some have called into question whether an Edwardsean account is adequate for making sense of original sin this does not take away from EAC's usefulness as a starting point for formulating a doctrine of original sin. Furthermore, this account, or an account like this, might also help make sense of the doctrine of atonement. One common objection against penal substitutionary theories of atonement is that it would be unjust for God to allow someone, namely Christ, to bear someone else's punishment if the substitute is completely innocent. David Lewis has made the interesting point that we do allow for penal substitution for pecuniary offences. (Lewis: 1997) However most people's intuition is that substitution is unjust when a crime is very serious, e.g. murder. When it concerns non-pecuniary offenses the perpetrator must face the penalty themselves. To allow someone else to act as a substitute would seem to be a terrible act of injustice. EAC might help those who seek to defend the justice of a penal substitutionary account of atonement. Briefly, here is how. In order for penal

\footnotetext{
${ }^{27}$ One might be inclined to wonder whether the emphasis on God's sovereignty is actually a strength of this model. For example, one might think: "If this model only works with a concept of divine fiat, it seems that all possible metaphysical accounts which attempt to identify identity criteria are deficient because they delimit God's sovereignty. If this is the case, then why use metaphysics at all if the very nature of the account seems to exclude metaphysics from the very beginning?" First, I take it that the existence of criteria of identity do not necessarily delimit God's sovereignty. Thus, attempting to identify identity criteria might still be a worthwhile task (if such criteria could actually be identified is a different question). We can still do metaphysics. Second, I take it that there may be some models of resurrection which retain God's sovereignty but do not make reference to divine fiat. There reference to God's sovereignty in the matter of resurrection would, in those cases, be a strength of those accounts, as I take it this is a strength of the account proposed here.

${ }^{28}$ For an account which bears some similarity to what I have said in this paragraph (and even expresses its own similarity to Edwards's theology) see (Davis 2010, 19-32).
} 


\section{CHRISTOPHER WOZNICKI}

substitutionary atonement to be just one would need to give an account of how the penal consequences of sin are transferred to Christ. One way to do this would be to give an account in which Christ and the elect form one metaphysical whole. EAC gives us one way in which to form such an account. With EAC in hand we can say that Christ and the elect are different temporal and spatial parts of one metaphysical entity. This is because God treats or makes the spatial and temporal parts one in virtue of divine fiat. Thus, because Christ is one part of the same object as the elect, Christ can justly take upon himself the penal consequences of entire object. It should be noted that this is not a fully developed defense of the justice of penal substitutionary atonement, nevertheless, our discussion here suggests that EAC might be helpful for thinking about some of the puzzles involved in atonement theology. Thus, we might consider EAC's ability to make sense of make sense of the doctrine of redemption, as well as creation and new creation without needing to posit radically different metaphysical explanations for human beginnings, new beginnings, and human endings a neat feature of the account.

\subsection{Objections to Edwardsean Anti-Criterialism}

Despite EAC's numerous strengths, there are some weakness as well. One of the major weaknesses of EAC is that it is a version of anti-criterialism. There are several philosophical objections directed towards anti-criterialism, however given that this is a theological paper I will focus on theological objections to anti-criterialism. ${ }^{29}$ Matt Duncan presents us with the one example of a theological objection, he argues that theists, in particular, have reason for rejecting anti-criterialism in general (as opposed to EAC); this is because anti-criterialism potentially leads to the denial of some important theistic beliefs. Using the biblical account of Elijah's ascension, ${ }^{30}$ Duncan claims that anti-criterialism calls into question two important beliefs that many theists have about God: (1) that God is honest essentially and (2) that God promises salvation to those who follow him. Duncan believes that anti-criterialism calls into question these two beliefs. Duncan says,

"If Elijah could be possibility distinct from Elijah*, then God could possibly be dishonest. For Elijah followed God, and so God's promise [to salvation] applies to Elijah. But again, its possibly Elijah*, not the righteous Elijah, who receives eternal salvation. Thus it looks like God is possibly dishonest with respect to Elijah." (Duncan 2014: 294)

Duncan's point is that if anti-criterialism is true, then it is possible that Elijah and Elijah* are not the same person, thus making God dishonest about his promise to Elijah

\footnotetext{
${ }^{29}$ For some recent philosophical defenses of anti-criterialism see (Langford 2017, 613-630), (Langsam 2001, 247-271), (Lowe 2009), and (Madell 1981)

${ }^{30} 2$ Kings 2:1-17.
} 
regarding salvation. If this state of affairs obtains, it denies scriptural evidence that God is necessarily honest and keeps his promises. Given this apparent conflict, theists have special reasons to reject anti-criterialism on theological grounds. Does this objection hit the mark? I believe it does not. It seems as this objection is just begging the question. EAC explicitly states that Elijah and Elijah* are just the same persons. Why? Because of divine fiat. God declares Elijah and Elijah* to be numerically identical, thus they are numerically identical. If God's declaration is what makes the proposition "Elijah is Elijah*" true then Duncan's claim that "If Elijah could be possibly distinct from Elijah*, then God could possibly be dishonest" is false, because once the declaration that "Elijah is Elijah*" has been made it is simply the case that Elijah* who receives eternal salvation just is the same Elijah that followed God. All this to say, divine fiat makes it so that it is not possible that "Elijah could be possibility distinct from Elijah*." Thus EAC escapes Duncan's worry.

A second, but closely related worry is EAC reduces to a replica view of resurrection identity. The replica view is eloquently articulated by John Hick, although it has other defenders. ${ }^{31}$ Hick asks us to suppose that a certain man - John Smith - living in the United States suddenly and inexplicably disappears. At that same exact moment an exact replica of him appears in India. The person who appears is exactly similar in physical and mental characteristics. Hick asks us to suppose that,

"There is continuity of memory, complete similarity of bodily features including fingerprints, hair and eye coloration, and stomach contents, and also of beliefs, habits, emotions, and mental dispositions. Further, the "John Smith" replica thinks of himself as being the John Smith who disappeared in the United States." (Hick 1983: 126)

For all intents and purposes "John Smith" just is John Smith. Furthermore, Hick asks us to suppose that on John Smith's death the "John Smith" replica appears, not in India, but "as a resurrection replica in a different world altogether." This scenario "provides a model by which one may begin to conceive of the divine re-creation of the embodied human personality." (Hick 1983: 127) The problem with this model is that, contrary to what is required by orthodoxy, identity is qualitative rather than numerical. One worry we might have about the EAC explanation of resurrection identity is that it reduces to something like this replica view. Say that God re-creates Jones's body after it is cremated. Let us even say that God uses different matter, which is configured Joneswise. Some might say this is not actually Jones, it is a replica of Jones. Even if God treats the re-created Jones as Jones, it really isn't Jones, it is a Jones replica which is qualitatively a lot like Jones, even exactly like Jones, but not actually Jones. The

\footnotetext{
31 A version of the replica view, or something very similar to it seems to be articulated by Joel Green in (Green 2008, 179) and is possibly articulated by John Polkinghorne, (Polkinghorne 2006, 98). However whether or not Polkinghorne's view reduces to a replica model is up for debate.
} 


\section{CHRISTOPHER WOZNICKI}

Edwardsean Anti-Criterialist would deny this. Resurrection Jones is not a "replica" of Jones, resurrection Jones, under EAC, is numerically identical with Jones because of divine fiat. An objector might reply, that this is a divine fiction, resurrection Jones is actually a replica, much like Hick's replica. The Edwardsean Anti-Criterialist would deny that this is a fictional account, since identity by this account does not have any criteria. Jones's identity with resurrection Jones is by divine fiat.

Looking at two major theological worries that one might have about an Edwardsean Anti-Criterialist account about resurrection identity, it seems as though theologically the EAC solution might not be too problematic. In fact, the EAC solution has some significant positive consequences. Given the value of these consequences, it ought to be considered a viable option for addressing the problem of resurrection and personal identity.

\section{Conclusion}

Throughout the centuries the church has proclaimed, "For since we believe that Jesus died and rose again, even so, through Jesus, God will bring with him those who have died." 32 This belief, in the resurrection of believers, which is affirmed in scripture, creeds, confessions, and statements of faith, is more than just a part of Christian dogmatics, it is central to the gospel message. Because of its centrality to the gospel many have wondered how it will be accomplished by God. Various ways have been proposed, some of which were covered above. However, we have suggested one way to explain how a person's pre- and post-resurrection identity is identical. We have dubbed this way Edwardsean Anti-Criterialism. Under this view God treats or constitutes these pre- and post-resurrection bodies as numerically identical. In virtue of divine fiat they are simply one. To some this might come as a surprising solution to the problem of resurrection and personal identity. It might seem arbitrary to say that God, by his divine word, would simply make things be. However, that God could make things that previously weren't the case come to be, purely by divine fiat, should not be too surprising. After all, in his first acts of creation God speaks and brings things that once were not, into existence. Why could it not be the case that God's first acts of new creation might be similar? God speaks, and pre-resurrection bodies are now numerically identical with resurrection bodies. Given the creative power of God's word, that does not seem too far-fetched. ${ }^{33}$

\footnotetext{
321 Thessalonians 4:14 (NRSV)

${ }^{33}$ I would like to thank Fuller Theological Seminary's Analytic Theology for Theological Formation team (Oliver Crisp, James Arcadi, J.T. Turner, Jordan Wessling, and Jesse Gentile), the referees, and VeliMatti Kärkkäinen for helpful comments on this essay.
} 
“THUS SAITH THE LORD”

\section{Bibliography}

Baker, Lynne Rudder. 2007. The Metaphysics of Everyday Life. Cambridge: Cambridge University Press.

Crisp, Oliver. 2005. Jonathan Edwards and the Metaphysics of Sin. Burlington, VT: Ashgate. Davis, Stephen. 2002. "The Resurrection of the Dead." In Philosophy of Religion: A Reader and Guide, edited by William Lane Craig, Kevin Meeker, J.P. Moreland, Michael Murray, Timothy O'Connor, 520-523. New Brunswick, NJ: Rutgers University Press. Davis, Stephen. 2010. "Resurrection, Personal Identity, and the Will of God." In Personal Identity and Resurrection, edited by Georg Gasser, 19-32. Burlington, VT: Ashgate.

Duncan, Matt. 2014. “A Challenge to Anti-Criterialism." Erkenntnis 79 (2): 283-96.

Edwards, Jonathan. 1970. The Works of Jonathan Edwards Volume 3: Original Sin, edited by Clyde Hollbrook. New Haven: Yale University Press.

Edwards, Jonathan. 1980. The Works of Jonathan Edwards Volume 6: Scientific and Philosophical Writings, edited by Wallace Anderson. New Haven: Yale University Press.

Edwards, Jonathan. 1989. The Works of Jonathan Edwards Volume 8: Ethical Writings, edited by Paul Ramsey. New Haven: Yale University Press.

Gasser, Georg (2010) "Introduction." In Personal Identity and Resurrection, edited by Georg Gasser, 1-17. Burlington, VT: Ashgate.

Green, Joel. 2008. Body, Soul, and Human Life: The Nature of Humanity in the Bible. Grand Rapids, MI: Baker.

Hamilton, Mark. 2013. "Jonathan Edwards on the Atonement." International Journal of Systematic Theology 15 (4): 394-415.

Helm, Paul. 2003. "A Forensic Dilemma: John Locke and Jonathan Edwards on Personal Identity." In Jonathan Edwards: Philosophical Theologian, edited by Paul Helm and Oliver Crisp, 45-60. Burlington, VT: Ashgate Hick, John. 1983. Philosophy of Religion. Englewood Cliffs, NK: Prentice-Hall. Hudson, Hud. 2007. "I am not an Animal." In Persons Human and Divine, edited by Peter van Inwagen and Dean Zimmerman, 216-34. New York: Oxford University Press.

van Inwagen, Peter. 1978. "The Possibility of Resurrection." International Journal of Philosophy of Religion 9 (2): 114-21.

van Inwagen, Peter. 1988. The Possibility of Resurrection and Other Essays in Christian Apologetics. Boulder, CO: Westview Press.

Kvanvig, Jonathan and Hugh McCann. 1991. "The Occasionalist Proselytizer: A Modified Catechism." Philosophical Perspectives 5: 587-615.

Langford, Simon. 2017. "A Defence of Anti-Criterialism." Canadian Journal of Philosophy 47 (5): 613-630. 


\section{CHRISTOPHER WOZNICKI}

Langsam, Harold. 2001. "Pain, Personal Identity, and the Deep Further Fact." Erkenntnis 54 (2): 247-71.

Lee, Sang Hyun. 2000. The Philosophical Theology of Jonathan Edwards. Princeton, NJ: Princetone University Press.

Lewis, David. 1997. “Do We Believe in Penal Substitution?" Philosophical Papers 26 (3): 203-209.

Lowe, Edward Jonathan. 2009. More Kinds of Being: A Further Study of Inviduation, Identity, and the Logic of Sortal Items. Oxford: Wiley-Blackwell.

Madell, Geoffrey. 1981. The Identity of the Self. Edinburgh: Edinburgh University Press. Merricks, Trenton. 1998a. "There are no Criteria of Identity over Time" Nous 32(1): 106124.

Merricks, Trenton. 1998b. "The Resurrection of the Body and Life Everlasting." In Reasons for the Hope Within, edited by Michael Murray, 261-286. Grand Rapids: Eerdmans.

Merricks, Trenton. 2001. "How to Live Forever without Saving Your Soul: Physicalism and Immortality." In Soul, Body, and Survival: Essays on the Metaphysics of Human Persons, edited by Kevin Corcoran, 183-200. Ithaca: Cornell University Press

Noonan, Harold and Ben Curtis. 2017. "Identity." In The Stanford Encyclopedia of Philosophy, edited by Edward Zalta, (Spring 2017). https://plato.stanford.edu/archives/spr2017/entries/identity/.

Olson, Eric. 2016. "Personal Idenity" In The Stanford Encyclopedia of Philosophy, edited by Edward Zalta, (Spring 2017). https://plato.stanford.edu/archives/spr2016/entries/identity-personal/.

Peters, Ted. 1999. "Resurrection of the Very Embodied Soul?" In Neuroscience and the

Person: Scientific Perspectives on Divine Action, edited by Robert Russell, Nancey Murphy, Theo Meyering, and Michael Arbib, 305-26. Vatican City and Berkeley: Vatican Observatory and Center for Theology and the Natural Sciences.

Polkinghorne, John. 2006. "Anthropology in an Evolutionary Context." In God and

Human Dignity, edited by Soulen, R. Kendall Soulen and Linda Woodhead, 89-103. Grand Rapids: Eerdmans.

Quinn, Philip. 1983. "Divine Conservation, Continuous Creation, and Human Action."

In The Existence and Nature of God, edited by Alfred Freddoso, 55-80. Notre Dame: Notre Dame University Press.

Rea, Michael. 2007. "The Metaphysics of Sin." In Human and Divine, edited by Peter van Inwagen and Dean Zimmerman, 335-41. New York: Oxford University Press.

Schultz, Walter. 2016. "The Metaphysics of Jonathan Edwards's End of Creation." Journal of the Evangelical Theological Society 59 (2): 339-59.

Thiselton, Anthony. 2012. Life After Death: A New Approach to the Last Things. Grand Rapids: Eerdmans. 
“THUS SAITH THE LORD”

Turner, James. 2015. "We Look For the Resurrection of the Dead: An Analytic Theological Rethinking of the Intermediate State and Eschatological Bodily Resurrection in Christian Theology." PhD diss., University of Edinburgh.

Zimmerman, Dean. 1999. "The Compatibility of Materialism and Survival: The 'Falling Elevator' Model.'" Faith and Philosophy 16 (2): 194-212.

Zimmerman, Dean. 2010. "Bodily Resurrection: The Falling Elevator Model Revisited." In Personal Identity and Resurrection, edited by Georg Gasser, 33-50. Burlington, VT: Ashgate. 